\title{
Plant Patents-A Boon to Horticulture and the
} American Public

\author{
R. J. Hutton ${ }^{1}$
}

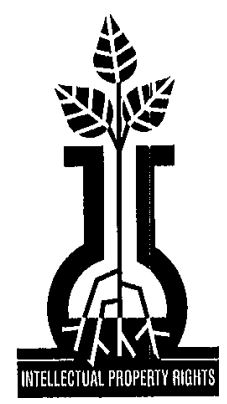

Summary. The Plant Patent Act of 1930 was a tremendous step forward in the development of new cultivars for ornamental horticulture and for the benefit of the American public. The 'Peace' rose, PP 591, was the single breakthrough that had maximum impact. Prom the Plant Patent Act, other forms of breeders' rights were spawned worldwide, including our own Plant Variety Protection Act (PVPA). Proof of the success has been the increasing use and acceptance of plant patents and the lack of challenges to the act and plant patent litigation.

I n the 1920s, Paul Stark and his brothers of the Stark Nursery and Orchard Co., Louisiana, Mo., with support from Luther Burbank, Thomas A. Edison, and other interested persons, persuaded the U.S. Congress that plant breeders should have the same rights as other inventors. [The constitutional provision for our patent system is Art. 1, Sec. 8. "The Congress shall have the power. . . To promote the progress of science and the useful arts, by securing for limited times to authors and inventors the exclusive right to their respective writings and discoveries."] The result was the Townsend-Purnell Plant Patent Act, an amendment to the general patent law passed by Congress and signed by President Hoover on 23 May 1930. 
As presented before the Senate at that time it was:

"To afford agriculture so far as practicable the same opportunity to participate in the benefits of the Patent system as has been given industry and thus assist in placing agriculture on a basis of economic equality with industry."

\section{The report went on to state:}

"Today the plant breeder has no adequate financial incentive to enter upon this work...Today plant breeding and research is dependent in large part upon government funds to Government Experiment Stations or the limited endeavors of the amateur breeder. It is hoped that the bill (before you) will afford a sound basis for investing capital in plant breeding and consequently stimulate plant development through private funds."

Even though plant patents are limited to asexually propagated plant cultivars, the Plant Patent Act has attained well its purpose and the intent of Congress. Plant Patent (PP)1 was issued to Henry Bosenberg, a rose nurseryman of New Brunswick, N.J., on 18 Aug. 1931. The cultivar covered by PP1 was named 'New Dawn'. By the end of 1992, there had been 8081 plant patents issued-more than half of these in the past 16 years.

Has the Plant Patent Act been successful? You bet it has! The success has been far beyond anything imagined by the Stark broth ers, Luther Burbank, Edison, or the U.S. Congress.

My own interest and knowledge of plant patents has been exclusively with hardy ornamentals, primarily roses. It is from this segment of the horticultural industry that I speak, but I have been active in the National Assn. of Plant Patent Owners (NAPPO) for more than 30 years. I was also a member of the United States Delegation to the 1980 session of the International Union for the Protection of New Varieties of Plants (UPOV), and have visited many of the European plant breeders' rights offices. At our nursery, we also have entertained UPOV delegations to the United States. My experience has been focused, my interests broad.

Here at The Conard-Pyle Co., we have no breeding program of our own. Instead, we have specialized in obtaining new plants created by others to take to the market. We have been associated with The House of Meilland, Antibes, France, for 60 years. They are specialists in breeding roses that have been patented wherever possible, and then introduced and licensed worldwide since World War II. We introduced their PP591, which covered the 'Peace' rose, still the most popular rose worldwide. We have introduced new roses and other plants from amateur and professional breeders who lacked access to the U.S. market.

Among our other patented introductions are the widely acclaimed Ilex $\times$ meserveae, known as the Blue hollies and China hollies, created by Kathleen H. Meserve. They were a major breakthrough in red-berried, glossyleaved "Christmas"-type hollies of extended hardiness.

Ernest Schwartz, an auto mechanic near Baltimore, Md., was interested in roses and studied rose breeding. He allowed us to evaluate his seedlings, and from these we selected his Number 6333, which became PP2463, issued 16 Dec. 1964 and named 'Sea Foam'. It has proven to be one of the most diseasefree of existing shrub roses. Another rose, PP3097, 'Portrait', was the first rose created by an amateur to receive the prestigious award from Al-America Rose Selections. Carl Meyer, the creator, was by profession a pipe fitter. $\mathrm{He}$, too, loved roses and was not intimidated by what he didn't know.

The Plant Patent Act was the forerunner of breeders' property rights worldwide. At this time, there is an ever-increasing need for such property rights to encourage the significant investment needed to support research and reward all types and levels of plant breeding. There is tremendous demand for new cultivars at the consumer level and great need at the environmental level.

France was the second country to grant breeders' rights, but not in the form of patents. They developed a system that has been copied in many countries and is the system encouraged by UPOV under the World Intellectual Property Organization (WIPO).

Over the years, there have been relatively few legislative, regulatory, or legal threats to the Plant Patent Act. The most serious threat came in the late 1960s, when a patent attorney encouraged the ASTA and other interests to advocate changing the act to cover seedpropagated varieties. In the mind of this patent attorney, the most practical solution was simply to delete the word "asexually" from Section 161. Patents for Plants and Section 163. Grant of Chapter 15-Plant Patents (U.S. Patent Office, 1979).

When this movement surfaced, there was a great hue and cry from those using the Plant Patent Act. The basis for objecting was the lack of uniformity in many seed-grown crops, which would weaken the system.

Another problem was that the seed industry was not unified, in that a group wanted to exclude six vegetables for seemingly "po-

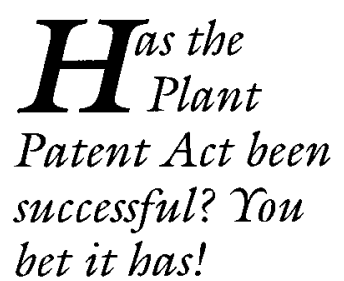


$\prod_{\text {Patent Act }}^{\text {he Plant }}$ has been successful for a number of

reasons. litical reasons." This became known as the "soup exemption," and would have complicated the Plant Patent Act additionally.

Problems between the vegetively propagated plant group and the seed industry evaporated when the plant patent attorney advocating changes in the Plant Patent Act dropped from view. All was resolved when the Plant Variety Protection Act passed in 1970.

The Plant Patent Act has been successful for a number of reasons. Perhaps the most important is that it came into being at the right time...just before it was needed; and because it served as a "spark" to ignite interest in plant breeding and brought to the market many significant new plants just before and immediately following World War II.

The success of the 'Peace' rose brought the acceptance of plant patents and the system of licensing first to the garden rose business, and then to other areas of the nursery industry, especially fruit, flowering, and shade trees. By the early 1960s, plant patents and licensing policies had been accepted throughout most of the woody plant part of the nursery industry.

One area of the prominence and importance of plant patents to the rose business has been the development of cultivars for the production of fresh flowers. This is a narrow sector of the flower industry, but, with the popularity of roses in the fresh flower trade, it has been highly competitive, especially for hybrid tea roses, the large-flowered, longstemmed, red roses.

The first of these cultivars was 'Better Times', covered by PP23, issued 23 Aug. 1932. From the late 1930s until 1950, 'Better Times' commanded a major share of the florist market. It also brought into practice the licensing of the "use" of a plant patent, because the underglass flower growers did not sell the plants, but grew them exclusively for the production of flowers to harvest and market. The Joseph H. Hill Company of Richmond, Ind., instituted a system of licensing selected nurseries to produce plants of 'Better Times'. These plants were leased to underglass growers to plant and use for production of the flowers. At the end of the useful life of the plants, growers were required to destroy them and replant under a new lease. With each lease, a "use" royalty was assessed. The production life of a plant was several years, so the royalty has been a very minor cost per flower sold.

There have been significant improvements in breeding roses, especially for the fresh flower trade. Although there was no immediate successor to 'Better Times', PP2443 was issued in 1964 to the cultivar known as 'Forever Yours', from the E. G. Hill
Company. This was followed by PP4057, issued in 1977, also to the E. G. Hill Coinpany, covering the cultivar Royalty. Both of these dominated the market for the life of the respective plant patents.

Other red hybrid tea roses that came to prominence were PP1367, known as 'Baccara'; PP1982, known as 'Red American Beauty'; PP3059, known as 'Cara Mia'; and PP3727, known as 'Samantha'. Two cultivars-PP3452, known as Visa ${ }^{\circledR}$ 'Meired', and PP4391, known as 'Mme. Georges Delbard'-have not been grown widely in the United States, but have been significant in our market with flowers produced in South America. All of these were successful, but never reached the market share of 'Better Times', 'Forever Yours', and 'Royalty'. Other than red, the most important rose for fresh flower production has been 'Sonia', PP3095, which was a new shade of iridescent pink of exceptional form and long vase life.

Few, if any, of these roses would have come into existence, let alone met with success, without our U.S. Plant Patent system. Not only were they successful for the breeder and introducer (owner of the plant patent), but these roses benefited the growers, fresh flower wholesalers, and retailers. Even more important, improved products were available to the consumer. Benefits come to the consumer by having longer-lasting roses for better color and year-round availability.

\section{Plant patent litigation}

To the best of my knowledge, no plant patent has been successfully challenged and judged invalid. Over the years we have had several of our plant patents infringed. All but one was settled out of court, and in that one we were successful against the infringer in a somewhat hostile court.

Nearly all of our infringement situations have been settled reasonably, if not amicably. In many cases, infringement is a lack of knowledge, understanding oflicensing procedures, or even knowing the identity of the plant. On the other hand, some violations have been deliberate. In several cases, we have gone to the nursery with legal authority and destroyed plants in the nursery row. More often, we take the plants or have one of our licensees take them and sell them as their own. With such violations, we have the infringer sign a document stating they were growing unlicensed plants and would not do so again. Under some situations we have granted a license to the infringer where we were reasonably sure it was not a deliberate act and they had a generally good reputation within the industry.

These are all experiences shared by most plant patent owners. Even without trade press 
publicity it is amazing how the news of enforcement of plant patent rights gets around the trade.

Why has there been so little litigation of plant patents? First and foremost is that the Plant Patent Act is a part of U.S. Code, Title 35 , Patents, and is supported by all the legal actions that have taken place over 2 centuries. In addition, inventors and breeders of new plants have used discrimination in choosing the new cultivars on which they have submitted plant patent applications. There also have been plants patented that, from a technical patent standpoint, were different and distinctive but were not perceptively so in the market place; hence, they were not successful.

The breeders with whom we have worked arc aware of plant patents or other breeders' rights and understand what makes a variety patentable and commercially practical and successful. We work closely with these breeders in this respect, guiding them as is appropriate and necessary. Our problems with the Patent Office and examiners also have been minimal, and, where differences have existed, we have met with the examiners to understand their problems and needs.

I believe the Plant Patent system works well and has been of benefit to the development of ornamental horticulture, the environment, and all consumers. There is one area where the Plant Patent Act could and should be strengthened. As the law stands, the grant is of the right to exclude others from asexually reproducing the plant or selling or using the plant so reproduced. This does not clearly define rights to anything less than the whole plant-such as leaves, flowers, pollen, fruit, or any other plant parts. It is a gray area that needs clarification by appropriate legislation

In our firm, we have not found the need to use other forms of plant cultivar protection. So far, we are not working with sexually propagated plant cultivars, so the PVPA is not appropriate. We have begun to look at utility patents, but, to date, have not given them serious consideration. Copyrights, trademarks, and trade secrets are not appropriate substitutes for plant patent protection.

In recent years, we have begun using trademarks with some of our newly patented plants. Because the Patent Office started requesting that a cultivar name be made a part of the patent, we have begun using coined names that henceforward are the generic varietal names. To each of the patents we then assign a commercial synonym as the trademarked name. Some of these trademarks are registered with the Patent and Trademark Office. Our patent licensing agreement authorizes the use of the trademark with the patented plant. The trademarking of commercial synonyms is a new area so far without legal challenge and unproven in acceptance by the trade or the consumer.

These are times ofinnovation and change in all aspects of plant breeding and genetic manipulation as well as legal challenges and interpretations of many accepted systems and procedures in areas of intellectual property rights. Developments and challenges are certain to affect plant patents, but at this time we do not know what these changes might be.

At a symposium held in 1993, entitled "Intellectual Property Rights: Protection of Plant Materials" (Baenziger et al., 1993), the shortcomings, real or perceived, of plant patents, PVPA, and utility patents applied to plants were discussed. However, when a suggestion was made to create a new system to replace the three separate systems, there was a great protest that such a system could never be made to work. My answer is that we presently are using three different systems, whereas at one time each was said to be unworkable. A new system could be designed to fill the needs of all. It would take time and would need the complete support from all segments of the plant, scientific, and commercial worlds working in the plant kingdom.

In reality I feel very strongly that each of our systems is workable and gives a practical and reasonable choice to the developers of intellectual property. Minor revisions may be appropriate and desirable for the PVPA and Plant Patent Act, but let's keep what has proven to be workable.

\section{Literature Cited}

Baenziger, P.S., R.A. Kleese, and R.F. Barnes. 1993. Intellectual property rights: Protection of plant paterials. Crop Sci. Soc. of Amer, Amer. Soc. Agron, and Soil Sci. Soc. Amer., Madison, Wis. CSSA Spec. Publ. 21.

U.S. Patent Office. 1979. Patent Laws, Stock Number 003-004-00561-1, U.S. Government Printing Office, Washington, D.C.

hese are
times of
innovation and
change in all
aspects of plant
breeding and
genetic manipu-
lation as well as
legal challenges
and interpreta-
tions of many
accepted systems
and procedures
in areas of
intellectual
property rights.

property rights. 